\title{
Oriented Crystallization of Calcium Carbonate under Self-Organized Monolayers of Amide-Containing Phospholipids
}

\author{
Peter J . J . A. Buijnsters, ${ }^{\dagger, \neq}$ J ack J . J . M. Donners,\# Susan J . Hill, \\ Brigid R. Heywood, $\$$ Roeland J . M. Nolte, ${ }^{\ddagger} \#$ Binne Zwanenburg, ${ }^{\ddagger}$ and \\ Nico A. J . M. Sommerdijk*,\# \\ Department of Organic Chemistry, NSR-Center, University of Nijmegen, Toernooiveld 1 , \\ NL-6525 ED Nijmegen, The N etherlands, Laboratory of Macromol ecular and \\ Organic Chemistry, Eindhoven University of Technol ogy, Eindhoven, The Netherlands, \\ Birchall Centre for I norganic Chemistry and Materials Science, Kede University, \\ Kœle, United Kingdom
}

Received December 18, 2000. In Final Form: March 7, 2001

\begin{abstract}
In the presence of calcium ions amide-containing phospholipid $\mathbf{1}$ self-assembles to form well-defined two-dimensional domains at theair - water interface. Thesedomains act as templates for thecrystallization of cal cium car bonatethat efficiently nucl eate the growth of [10.0] oriented cal cite irrespective of thesurface concentration of thelipid. Responsible for this preference for nucleation at the (10.0) face is the formation of an intramolecular hydrogen bond between the phosphate group and the phenoxy moiety which forces the phosphate group to adopt a bidentate orientation toward the aqueous phase. It was shown that when this hydrogen bond was absent, that is, when the phosphate group is monomethylated, lateral pressure was required in order to enforce a similar conformation and accomplish the nucleation of [10.0] oriented calcite.
\end{abstract}

\section{Introduction}

Crystal formation in Nature is often mediated and regulated by highly organized organic surfaces of biopolymers. ${ }^{1}$ The processes involving crystallization are very well controlled, and the resulting crystals possess shapes and sizes that aredistinctly different from those obtained under abiotic conditions. ${ }^{2}$ The relationship between the templating biomolecular substrate and the inorganic phase lies in the epitaxial matching of lattice spacings of specific crystal planes with some or dered arrangement of molecular units in the template. ${ }^{3}$ To mimic and to understand biological mineralization, researchers have carried out different types of experiments. One approach has been to isolate the templating matrix from mineralized tissues and examine the growth of calcium salts in the presence of this matrix. ${ }^{4}$ Other experiments have focused on synthetic (bio-)organic templates, such as polymers, ${ }^{5}$ macromolecular complexes, ${ }^{6}$ phospholipid

* Corresponding author. E-mail: N.Sommerdijk@tue.nl.

† Present adress: Department of Medicinal Chemistry, J anssen Research Foundation, Beerse, Belgium.

$¥$ University of Nijmegen.

\#Eindhoven University of Technology.

$\S$ Keele University.

(1) Weiner, S. Crit. Rev. Biochem. 1986, 20, 365. (b) Mann, S.; Archibald, D. D.; Didymus, J . M.; Douglas, T.; Heywood, B. R.; Meldrum, F. C.; Reeves, N. J . Science 1993, 261, 1286.

(2) Addadi, L.; Weiner, S. Angew. Chem. 1992, 104, 159.

(3) Mann, S. Nature 1988, 332, 119.

(4) Addadi, L.; Weiner, S. Proc. Natl. Acad. Sci. U.S.A. 1985, 82 4110. (b) Addadi, L.; Weiner, S. Mol. Cryst. Liq. Cryst. 1986, 134, 305. (c) Albeck, S.; Weiner, S.; Addadi, L. Chem. Eur. J. 1996, 2, 278. (d) Levi, Y.; Albeck, S.; Brack, A.; Weiner, S.; Addadi, L. Chem. Eur. J. 1998, 4, 389. (e) Kniep, R.; Busch, S. Angew. Chem., Int. Ed. Engl. 1996, 35, 2624.

(5) Berman, A.; Ahn, D. J .; Lio, A.; Salmeron, M.; Reichert, A.; Charych, D. Science 1995, 269, 515. (b) Calvert, P.; Rieke, P. Chem. Mater. 1996, 8, 1715. (c) Reis, R. L.; Cunha, A. M.; Fernandus, M. H.; Correia, R. N. J . Mater. Sci. Mater. Med. 1997, 8, 897. (d) E pple, M.; Schwarz, K. Chem. Eur. J . 1998, 4, 1898. (e) Cölfen, H.; Antonietti, M. Langmuir 1998, 14, 582. vesicles, ${ }^{7} \beta$-pleated poly(amino acids) entrapped in gelatin, ${ }^{8}$ self-assembled monol ayers on gold substrates, ${ }^{9}$ and Langmuir films. ${ }^{10,11}$ In the case of Langmuir monolayers the amphiphilic molecules can be designed in such a way that they act as artificial two-dimensional nuclei for the promotion of crystal nucleation. Such films have been used as templates to direct the crystal nucleation and growth of aminoacids, ${ }_{11}^{11}$ ice, ${ }^{12}$ proteins,${ }^{13}$ and calcium car bonate. ${ }^{11}$

Initially, monolayer crystallization experiments were conducted on highly compressed surfactant films which acted as $2 \mathrm{D}$ crystals requiring the monolayer to match exactly one of thecrystal faces of thenucleating species. ${ }^{10,11}$ It was found that modification of the apolar part of the surfactant ${ }^{14}$ as well as theheadgrou ${ }^{15}$ had a marked effect

(6) Donners, J . J . J . M.; Heywood, B. R.; Meijer, E. W.; N olte, R. J M.; Roman, C.; Schenning, A. P. H. J .; Sommerdijk, N. A. J . M. Chem. Commun. 2000, 1937

(7) Mann, S.: Hannington, J. P.: Williams, R. J . P. Nature 1986, 324 565. (b) Ozin, G. A. Acc. Chem. Res. 1997, 30, 17.

(8) Falini, G.; Fermani, S.; Gazzano, M.; Ripamonti, A. Chem. Eur J . 1997, 3, 1807. (b) Falini, G.; Fermani, S.; Gazzano, M.; Ripamonti, A. Chem. Eur. 1998, 4, 1048.

(9) Archibald, D. D.; Quadri, S. B.; Gaber, B. P. Langmuir 1996, 12, 538. (b) Wurm, D. B.; Brittain, S. T.; Kim, Y.-T. J. Mater. Sci. Lett. 1996, 15, 1285. (c) Küther, I.; Nelles, G.; Seshadri, R.; Schaub, M.; Butt, H.-J .; Tremel, W. Chem. Eur. J . 1998, 4, 1834. (d) Küther, J Seshadri, R.; Tremel, W. Angew. Chem., Int. Ed. Engl. 1998, 37, 3044 Aizenberg, J .; Black, A. J .; Whitesides, G. M. J . Am. Chem. Soc. 1999, $121,4500$.

(10) Landau, E. M.; Levanon, M.; Leiserowitz, L.; Lahav, M.; Sagiv, J . Nature1985, 318, 353. (b) Landau, E. M.; Popovitz-Biro, R.; Levanon M.; Leiserowitz, L.; Lahav, M.; Sagiv, J . Mol. Cryst. Liq. Cryst. 1986, 134, 323.

(11) Mann, S.; Heywood, B. R.; Rajam, S.; Birchall, J . D. Nature 1988, 324, 692. (b) Landau, E. M.; Grayer Wolf, S.; Levanon, M.; Leiserowitz, L.; Lahav, M.; Sagiv, J. Am. Chem. Soc. 1989, 111, 1436. (c) Rajam, S.; Heywood, B. R.; Walker, J . B. A.; Mann, S.; Davey, R. J .; Birchall, J.D.J. Chem. Soc., FaradayTrans. 1991, 87, 727. (d) Heywood, B. R.; Mann, S. Chem. Mater. 1994, 6, 311.

(12) Popovitz-Biro, R.; Wang, J . L.; Majewski, J .; Shavit, E.; Leiserowtz, L.; Lahav, M. J. Am. Chem. Soc. 1994, 116, 1179.

(13) Ahlers, M.; Muller, W.; Reichert, A.; Ringsdorf, H.; Venzmer, J. Angew. Chem., Int. Ed. Engl. 1990, 29, 1269. 


\section{Chart 1}
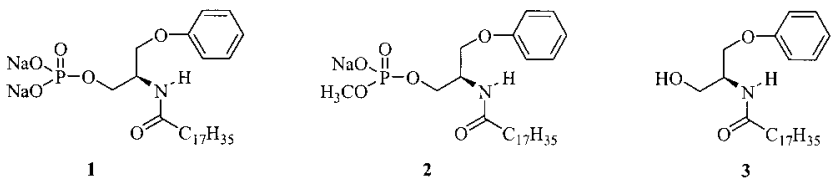

on the crystallization processes. Also, the mobility of the molecules in the monolayer turned out to havesignificant influence, viz. on the homogeneity and nucleation density of the crystallization as well as on the morphology of the overgrowth. Later hydrogen bonding functionalities, such as amide bonds, wereintroduced in the surfactants which could interlink the amphiphilic molecules into larger arrays, overcoming thenecessity tocompress themolecules into the desired organization in which they exert their nucleation effect. ${ }^{16}$

In previous work we reported on the aggregation behavior of amide-containing phospholipid surfactants which form highly organized, chiral aggregates in water and at the air-water interface. ${ }^{17}$ The expression of chirality on the supramolecular level could be achieved by fine-tuning the interactions between the molecules, for example by $\mathrm{pH}$ variation or metal ion complexation. In this work we al ready demonstrated that the aggregate morphol ogy of theamide-containing phosphol ipid $\mathbf{1}$ (Chart 1) can be altered through compensation of headgroup charge. I t was expected, therefore, that addition of cal cium ions could be used to further structure the highly organized assemblies of phospholipid $\mathbf{1}$. It was anticipated that such assemblies of these self-organized amphiphilic molecules could serveas well-defined templates directing the crystallization of inorganic compounds, in particular $\mathrm{CaCO}_{3}$.

\section{Experimental Section}

Synthesis. Thin-layer chromatography analyses were performed on Merck precoated silica gel 60 F 254 plates $(0.25 \mathrm{~mm})$ using the solvent mixtures indicated, and spots were visualized with UV and/or using ammonium molybdate ( $25 \mathrm{~g} / \mathrm{L})$ and ceric ammonium sulfate $(10 \mathrm{~g} / \mathrm{L})$ in $10 \%$ aq $\mathrm{H}_{2} \mathrm{SO}_{4}$. Phosphate containing compounds were visualized using $\mathrm{K}$ night and $\mathrm{Y}$ oung ${ }^{18}$ spray. Flash column chromatography was performed on Merck kieselgel $60 \mathrm{H}(0.005-0.040 \mathrm{~mm})$ using a pressure of $\sim 0.5$ bar using the eluents indicated. Melting points were measured on a Reichert thermopan microscope. Optical rotations were de termined at $20^{\circ} \mathrm{C}$ using a Perkin-E Imer automatic polarimeter, model 241. Routine FT-IR spectra were recorded using a Biorad WI N-IR FTS-25 single-beam spectrometer. ${ }^{1} \mathrm{H},{ }^{13} \mathrm{C}$, and ${ }^{31} \mathrm{P} N M \mathrm{R}$ spectra were recorded on a Bruker AC 300 (300/75.1/121 MHz) spectrometer. Chemical shifts are reported in ppm $(\delta)$ relative to $\mathrm{Me}_{4} \mathrm{Si}$ or trimethyl phosphate as internal standard. Mass spectra were recorded with a double-focusing VG 7070E spectrometer. Elemental analyses wereperformed with a CarloE rba Instruments EA 1108 element analyzer.

Disodium (-)-(2S)-3-Phenoxy-2-octadecanoylaminopropan-1-yl Phosphate (1). This compound was synthesized according to the procedure of Sommerdijk et al. ${ }^{19} \mathrm{Mp}$ 145-147 ${ }^{\circ} \mathrm{C} . \mathrm{R}_{\mathrm{f}}=0.30\left(\mathrm{MeOH} / \mathrm{H}_{2} \mathrm{O} / \mathrm{CHCl}_{3}, 39 / 10 / 67, \mathrm{v} / \mathrm{v} / \mathrm{v}\right) . \mathrm{t}_{\mathrm{R}}=14.20 \mathrm{~min}$ (capillary electrophoresis). $[\alpha]_{\mathrm{D}} 20-22.1$ (c $=1.0, \mathrm{CHCl}_{3} / \mathrm{MeOH}$,

(14) Landau, E. M.; Wolf, S. G.; Levanon, M .; Leiserowtz, L .; Lahav, M.; Sagiv, J . J. Am. Chem. Soc. 1989, 111, 1436.

(15) Mann, S.; Heywood, B. R.; Rajam, S.; Walker, J . B. A. J . Phys. Appl. Phys. 1991, 24, 154. (b) Heywood, B. R.; Mann, S. Chem. Mater. 1994, 6, 311.

(16) Cooper, S. J .; Sessions, R. B.; Lubetkin, S. D. J . Am Chem. Soc. 1998, 120, 2090. (b) Champ, S.; Dickinson, J. A.; Fallon, P. S.; H eywood, B. R.; Mascal, M. Angew. Chem., Int. Ed. Engl. 2000, 39, 2716.

(17) Sommerdijk, N. A. J . M.; Buijnsters, P. J . J . A.; Akdemir, H.; Geurts, Pistorius, A. M. A.; F eiters, M. C.; Nolte, R.J . M.; Zwanenburg, B. Chem. Eur. J. 1998, 4, 127.

(18) Knight, R. H.; Young, L. Biochem. J . 1958, 70, 111.
9/1 (v/v)). ${ }^{31} \mathrm{P} N M R\left(\mathrm{CDCl}_{3}\right): \delta=-0.751 \mathrm{ppm}$. IR $(\mathrm{KBr}): v=$ $3300(\mathrm{~N}-\mathrm{H}) \mathrm{cm}^{-1}, 3090(\mathrm{C}-\mathrm{H}$, aryl $), 2915,2840(\mathrm{C}-\mathrm{H}$, alkyl), 1630 (Am I), $1600(\mathrm{C}=\mathrm{C}$, aryl), 1545 (Am II), $1240(\mathrm{P}=\mathrm{O})$. MS $\left[\mathrm{FAB}^{+}, \mathrm{m} / \mathrm{z}\right]=580\left[\mathrm{M}+\mathrm{Na}^{+}\right], 557\left[\mathrm{M}^{+}\right]$. Anal. Calcd for $\mathrm{C}_{27} \mathrm{H}_{46}$ $\mathrm{NO}_{6} \mathrm{PNa}_{2} \cdot 3.5 \mathrm{H}_{2} \mathrm{O}: \mathrm{C}, 51.50 ; \mathrm{H}, 8.64 ; \mathrm{N}, 2.22$. Found: C, 51.18; $\mathrm{H}, 8.12 ; \mathrm{N}, 2.33$.

Benzyl (-)-(2S)-3-Phenoxy-2-octadecylaminopropan-1yl Methyl Phosphate. Anhydrous sodium iodide(132 mg, 0.880 $\mathrm{mmol}$ ) was added to a stirred sol ution of di benzyl (2S)-3-phenoxy2-octadecanoylaminopropan-1-yl phosphate $(534 \mathrm{mg}, 0.770 \mathrm{mmol}$ ) in dry acetone $(6 \mathrm{~mL})$ and heated under reflux for $3 \mathrm{~h}$ and subsequently left to stand for $48 \mathrm{~h}$ at $-20^{\circ} \mathrm{C}$, after which a white precipitate was obtained. ${ }^{20}$ This precipitate was washed with cold acetone $(5 \times 5 \mathrm{~mL})$, dried under reduced pressure, dissolved in dry acetone $(75 \mathrm{~mL})$, treated with ion-exchange resin $(3 \mathrm{~g}$, Dowex 50WX20, $\mathrm{H}^{+}$-form), and finally heated under reflux for $5 \mathrm{~h}$. The ion-exchange resin was removed by filtration, and the filtrate was concentrated in vacuo. Theresidue was treated with diazomethane in diethyl ether $(10 \mathrm{~mL}, 0.3 \mathrm{M})$, stirred overnight, and concentrated in vacuo, after which the remaining material was purified by flash column chromatography $\left(\mathrm{Si}_{2} \mathrm{O}\right.$, hexane/ ethyl acetate, $3: 1(\mathrm{v} / \mathrm{v}))$ to give $143 \mathrm{mg}(30 \%)$ of the product as a col orless oil. $\mathrm{R}_{\mathrm{f}}=0.30\left(\mathrm{Si}_{2} \mathrm{O}\right.$, hexane/ethyl acetate, 3:1 (v/v)). $[\alpha]^{20}{ }_{\mathrm{D}} \approx 0\left(\mathrm{c}=1.0, \mathrm{CHCl}_{3}\right) .{ }^{1} \mathrm{H} \mathrm{NMR}\left(\mathrm{CDCl}_{3}, 300 \mathrm{MHz}\right): \delta=$ 7.36-6.88(m, 1OH, OC $\left.\mathrm{H}_{5}, \mathrm{OCH}_{2} \mathrm{C}_{6} \mathrm{H}_{5}\right), 6.34(\mathrm{~m}, 1 \mathrm{H}, \mathrm{NH}), 5.07-$ $5.03\left(\mathrm{~m}, 2 \mathrm{H}, \mathrm{OCH}_{2} \mathrm{C}_{6} \mathrm{H}_{5}\right), 4.50-4.48(\mathrm{~m}, 1 \mathrm{H}, \mathrm{C}(\mathrm{O}) \mathrm{NHCH}), 4.30-$ $3.93\left(\mathrm{~m}, 4 \mathrm{H}, \mathrm{CH}_{2} \mathrm{OC}_{6} \mathrm{H}_{5}, \mathrm{CH}_{2} \mathrm{OP}(\mathrm{O})\left(\mathrm{OCH}_{3}\right)\right), 3.71-3.66(\mathrm{~m}, 3 \mathrm{H}$, $\left.\mathrm{OP}(\mathrm{O})\left(\mathrm{OCH}_{3}\right)\right), 2.15\left(\mathrm{t}, J=6.9 \mathrm{~Hz}, 2 \mathrm{H}, \mathrm{C}_{16} \mathrm{H}_{33} \mathrm{CH}_{2} \mathrm{C}(\mathrm{O})\right), 1.61(\mathrm{~m}$, $\left.2 \mathrm{H}, \mathrm{C}_{15} \mathrm{H}_{31} \mathrm{CH}_{2} \mathrm{CH}_{2} \mathrm{C}(\mathrm{O})\right), 1.26\left(\mathrm{~m}, 28 \mathrm{H}, \mathrm{CH}_{3}\left(\mathrm{CH}_{2}\right)_{14}, \mathrm{C}_{2} \mathrm{H}{ }_{4} \mathrm{C}(\mathrm{O})\right)$, $0.94\left(\mathrm{t}, \mathrm{J}=7.6 \mathrm{~Hz}, 3 \mathrm{H}, \mathrm{CH}_{3} \mathrm{CH}_{16} \mathrm{C}(\mathrm{O})\right) .{ }^{13} \mathrm{C} \mathrm{NMR}\left(\mathrm{CDCl}_{3}, 75\right.$ $\mathrm{MHz}): \delta=173.90(\mathrm{C}(\mathrm{O}) \mathrm{NH}), 158.81$ (quart $\left.\mathrm{CH}_{2} \mathrm{OC}_{6} \mathrm{H}_{5}\right), 136.22$, 136.14 (quart $\mathrm{P}(\mathrm{O}) \mathrm{CH}_{2}\left(\mathrm{OC}_{6} \mathrm{H}_{5}\right)$ ), $130.20\left(\mathrm{P}(\mathrm{O}) \mathrm{CH}_{2}\left(\mathrm{~m}-\mathrm{OC}_{6} \mathrm{H}_{5}\right)\right.$ ), $129.40\left(\mathrm{P}(\mathrm{O}) \mathrm{CH}_{2}\left(\mathrm{o}-\mathrm{OC}_{6} \mathrm{H}_{5}\right)\right), 122.31\left(\mathrm{~m}-\mathrm{CH}_{2} \mathrm{OC}_{6} \mathrm{H}_{5}\right), 128.65(\mathrm{P}(\mathrm{O})$ $\left.\mathrm{CH}_{2}\left(\mathrm{p}-\mathrm{OC}_{6} \mathrm{H}_{5}\right)\right), 121.95\left(\mathrm{p}-\mathrm{CH}_{2} \mathrm{OC}_{6} \mathrm{H}_{5}\right), 115.17\left(\mathrm{o}-\mathrm{CH}_{2} \mathrm{OC}_{6} \mathrm{H}_{5}\right)$, $70.35,70.27 \mathrm{P}(\mathrm{O}) \mathrm{CH}_{2}\left(\mathrm{OC}_{6} \mathrm{H}_{5}\right), 66.72,66.64\left(\mathrm{CH}_{2} \mathrm{OP}(\mathrm{O}) \mathrm{CH}_{2}\right), 65.78$ $\left(\mathrm{CH}_{2} \mathrm{OC}_{6} \mathrm{H}_{5}\right), 55.18,55.10\left((\mathrm{O}) \mathrm{P}\left(\mathrm{OCH}_{3}\right)\right), 37.27\left(\mathrm{CH}_{2} \mathrm{C}(\mathrm{O}) \mathrm{NH}\right)$, 32.57-23.33 $\left(\mathrm{CH}_{3}\left(\mathrm{CH}_{2}\right)_{15} \mathrm{CH}_{2} \mathrm{C}(\mathrm{O})\right), 14.76\left(\mathrm{CH}_{3}\left(\mathrm{CH}_{2}\right)_{15} \mathrm{CH}_{2} \mathrm{C}(\mathrm{O})\right)$. 31P NMR $\left(\mathrm{CDCl}_{3}, 121 \mathrm{MHz}\right) \delta=-2.14,-2.20 \mathrm{ppm}^{21} \mathrm{MS}^{2} \mathrm{FAB}^{+}$ $\mathrm{m} / \mathrm{z}]=640\left[\mathrm{M}+\mathrm{Na}^{+}\right], 618\left[\mathrm{M}+1^{+}\right]$.

Sodium (-)-(2S)-3-Phenoxy-2-octadecylaminopropan-1yl Methyl Phosphate (2). Benzyl (2S)-3-phenoxy-2octadecylaminopropan-1-yl methyl phosphate $(142 \mathrm{mg}, 0.230 \mathrm{mmol})$, dissolved in methanol $(50 \mathrm{~mL})$, was subjected to hydrogenolysis for $1 \mathrm{~h}$ with $\mathrm{Pd}(\mathrm{C})$ as the catalyst. The catalyst was removed using a small RP-18 column washed with hot methanol $(5 \times 25$ $\mathrm{mL})$, and the filtrate was concentrated in vacuo to a volume of approximately $25 \mathrm{~mL}$ before $10 \mathrm{~mL}$ of water containing $\mathrm{NaOH}$ $(4.5 \mathrm{mg}, 0.113 \mathrm{mmol})$ was added. This solution was treated with Dowex 50WX20 ( $\mathrm{Na}^{+}$-form) and lyophilized to afford $126 \mathrm{mg}$ (100\%) of 2 as a whitehygroscopic, fluffy powder. $\mathrm{R}_{\mathrm{f}}=0.50\left(\mathrm{CHCl}_{3} /\right.$ $\left.\mathrm{MeOH} / \mathrm{H}_{2} \mathrm{O}, 67 / 39 / 10\right) . \mathrm{t}_{\mathrm{R}}=12.91 \mathrm{~min}$ (capillary el ectrophoresis). $[\alpha]^{20}{ }_{\mathrm{D}}-8.3\left(\mathrm{c}=1.0, \mathrm{CHCl}_{3}\right) .{ }^{31} \mathrm{P} \mathrm{NMR}\left(\mathrm{CDCl}_{3}, 121 \mathrm{MHz}\right) \delta$ -0.4881 . IR $\left(\mathrm{KBr}, \mathrm{cm}^{-1}\right): v 3600-3200\left(\mathrm{H}_{2} \mathrm{O}\right), 3030(\mathrm{C}-\mathrm{H}$ aromatic), 2918, 2850 (C-H alkyl), 1643 (Am I), 1543 (Am II), $1467\left(\mathrm{C}-\mathrm{H}\right.$ deformation, al kyl), $1246(\mathrm{P}=\mathrm{O})$. MS $\left(\left(\mathrm{FAB}^{+}\right) ; \mathrm{m} / \mathrm{z}\right)$ : $1121\left[\mathrm{M}_{2}+\mathrm{Na}+1^{+}\right], 572\left[\mathrm{M}+\mathrm{Na}^{+}\right], 550\left[\mathrm{M}+1^{+}\right]$. Anal. Calcd for $\mathrm{C}_{28} \mathrm{H}_{49} \mathrm{NO}_{6} \mathrm{PNa} \cdot 4 \mathrm{H}_{2} \mathrm{O}$ : C, 52.70; $\mathrm{H}, 8.30 ; \mathrm{N}, 2.19$. Found: $\mathrm{C}$, 52.40; H, 8.10; N, 2.14.

(-)-(2R)-3-Phenoxy-2-octadecanoylaminopropan-1-ol (3). Sodium iodide ( $10 \mathrm{mg}, 0.067 \mathrm{mmol}$ ) was added to a stirred solution of (-)-(2S)-1-octadecanoyl-2-phenoxymethylaziridine ${ }^{19}(172.8 \mathrm{mg}$, $0.417 \mathrm{mmol})$ in dry acetonitrile $(25 \mathrm{~mL})$. The reaction mixture was heated under reflux for $2 \mathrm{~h}$, and the resulting mixture was concentrated in vacuo. Dichloromethane $(25 \mathrm{~mL})$ was added to the residue, and the solution was washed with water $(3 \times 10$

(19) See Sommerdijk, N. A. J . M.; Buijnsters, P. J . J . A.; Akdemir, H.; Geurts, D. G.; Nolte, R. J . M.; Zwanenburg, B. J . Org. Chem. 1997, $62,4955$.

(20) See also: Zervas, L.; Dilaris, I. J . Am. Chem. Soc. 1955, 77, 5354

(21) During the course of the reaction sequence an additional stereogenic center is formed on the phosphorous atom which results in the formation of two diastereomers which are observed as two separate peaks in the ${ }^{31}$ P N M R spectrum. Seealso: (a) Stegerhoek, L.J .; Verkade, P. E. Recl. Trav. Chim. Pays-Bas 1958, 77, 133. (b) Gielkens, J. W.; Hoefnagel, M. A.; Stegerhoek, L. J .; Verkade, P. E. Recl. Trav. Chim. Pays-Bas 1958, 77, 656. 
$\mathrm{mL})$. The separated organic layer was dried $\left(\mathrm{Na}_{2} \mathrm{SO}_{4}\right)$, and the solvent was removed in vacuo. The residue (169.1 mg) was dissolved in ethanol ( $15 \mathrm{~mL})$, and to this solution was added oxalic acid ( $60 \mathrm{mg}, 0.67 \mathrm{mmol}$ ). The reaction mixture was heated under reflux for $3 \mathrm{~h}$ and then concentrated in vacuo. The residue was purified by flash column chromatography $\left(\mathrm{Si}_{2} \mathrm{O}\right.$, hexane/ ethyl acetate, $1: 1(\mathrm{v} / \mathrm{v}))$ to furnish $119 \mathrm{mg}(66 \%)$ of $3 . R_{\mathrm{f}}=0.25$ $\left(\mathrm{Si}_{2} \mathrm{O}\right.$, hexane/ethyl acetate, $\left.1: 1\right)$. Mp 87.2-89.0 ${ }^{\circ} \mathrm{C}$. $[\alpha]^{20} \mathrm{D}-3.6$ $\left(\mathrm{c}=1.0, \mathrm{CHCl}_{3}\right) .{ }^{1} \mathrm{H} \mathrm{NMR}\left(\mathrm{CDCl}_{3}, 300 \mathrm{MHz}\right): \delta=7.36-6.89(\mathrm{~m}$, $\left.5 \mathrm{H}, \mathrm{OC}_{6} \mathrm{H}_{5}\right), 6.14(\mathrm{~m}, 1 \mathrm{H}, \mathrm{C}(\mathrm{O}) \mathrm{NHCH}), 4.32-4.27(\mathrm{~m}, 1 \mathrm{H}, \mathrm{C}(\mathrm{O})-$ $\mathrm{NHCH}), 4.18-4.07\left(\mathrm{ABX}, \mathrm{J}_{\mathrm{AX}}=4.11 \mathrm{~Hz}, \mathrm{~J}_{\mathrm{BX}}=4.78 \mathrm{~Hz}, \mathrm{~J}_{\mathrm{AB}}=\right.$ $\left.9.52 \mathrm{~Hz}, 2 \mathrm{H}, \mathrm{CH}_{2} \mathrm{OC}_{6} \mathrm{H}_{5}\right), 3.97-3.76(\mathrm{ABX}$, J $\mathrm{AX}=4.65 \mathrm{~Hz}$, J $\mathrm{BX}$ $=4.64 \mathrm{~Hz}$, J $\left.\mathrm{AB}_{1}=11.2 \mathrm{~Hz}, 2 \mathrm{H}, \mathrm{CH}_{2} \mathrm{OH}\right), 2.23(\mathrm{t}, \mathrm{J}=7.4 \mathrm{~Hz}, 2 \mathrm{H}$, $\left.\mathrm{C}_{16} \mathrm{H}_{33} \mathrm{CH}_{2} \mathrm{C}(\mathrm{O})\right), 1.64\left(\mathrm{~m}, 2 \mathrm{H}, \mathrm{C}_{15} \mathrm{H}_{31} \mathrm{CH}_{2} \mathrm{CH}_{2} \mathrm{C}(\mathrm{O})\right), 1.25(\mathrm{~m}, 28 \mathrm{H}$, $\left.\mathrm{CH}_{3}\left(\mathrm{CH}_{2}\right)_{14} \mathrm{C}_{2} \mathrm{H}_{4} \mathrm{C}(\mathrm{O})\right), 0.88$ (t, J $\left.=6.8 \mathrm{~Hz}, 3 \mathrm{H}, \mathrm{CH}_{3}\left(\mathrm{CH}_{2}\right){ }_{16}\right) .{ }^{13} \mathrm{C}$ $\mathrm{NMR}\left(\mathrm{CDCl}_{3}, 75 \mathrm{MHz}\right): \delta=174.49(\mathrm{C}(\mathrm{O}) \mathrm{NH}), 159.23$ (quat $\left.\mathrm{OC}_{6} \mathrm{H}_{5}\right), 130.23\left(\mathrm{~m}-\mathrm{OC}_{6} \mathrm{H}_{5}\right), 122.01\left(\mathrm{o}-\mathrm{OC}_{6} \mathrm{H}_{5}\right), 115.13\left(\mathrm{p} \mathrm{OC}_{6} \mathrm{H}_{5}\right)$ $67.89\left(\mathrm{CH}_{2} \mathrm{OC}_{6} \mathrm{H}_{5}\right), 63.54\left(\mathrm{CH}_{2} \mathrm{OH}\right), 51.07(\mathrm{CHNH}), 37.44-23.36$ $\left(\left(\mathrm{CH}_{2}\right)_{16} \mathrm{CH}_{3}\right), 14.80\left(\mathrm{CH}_{3}\left(\mathrm{CH}_{2}\right)_{16}\right)$. IR $\left(\mathrm{KBr}, \mathrm{cm}^{-1}\right): v 3668(\mathrm{O}-$ $\mathrm{H}), 3307(\mathrm{~N}-\mathrm{H}), 3100-3050$ ( $\mathrm{C}-\mathrm{H}$ aromatic), 2950-2850 (C-H alkyl), 1641 (Am I), 1549 (Am II). MS [EI m/z, rel int (\%)] = 433 $\left(\left[\mathrm{M}^{+}\right], 0.5\right), 415\left(\left[\mathrm{C}_{27} \mathrm{H}_{45} \mathrm{NO}_{2}^{+}\right], 2.6\right), 340\left(\left[\mathrm{C}_{21} \mathrm{H}_{42} \mathrm{NO}_{2}^{+}\right], 100\right), 284$ $\left(\left[\mathrm{C}_{18} \mathrm{H}_{38} \mathrm{NO}^{+}\right], 14.5\right), 94\left(\left[\mathrm{C}_{5} \mathrm{H}_{6} \mathrm{O}^{+}\right], 19.9\right)$. Anal. Calcd for $\mathrm{C}_{27} \mathrm{H}_{47^{-}}$ $\mathrm{NO}_{3} \cdot 0.25 \mathrm{H}_{2} \mathrm{O}: \mathrm{C}, 74.01 ; \mathrm{H}, 10.93 ; \mathrm{N}, 3.20$. Found: $\mathrm{C}, 74.01 ; \mathrm{H}$, 11.05; N, 3.16.

Capillary E lectrophoresis. The purity of compounds $\mathbf{1}$ and 2 was also checked with capillary electrophoresis (CE). The system consisted of a Hewlett-Packard CE apparatus operated at $30 \mathrm{kV}$ and $20^{\circ} \mathrm{C}$. A buffer $\left(\mathrm{Na}_{2} \mathrm{~B}_{4} \mathrm{O}_{7} / \mathrm{NaOH}, 50 \mathrm{mM}, \mathrm{pH}=9.3\right)$ containing $26.7 \mathrm{mM} \beta$-cyclodextrine (to prevent aggregate formation) was used, and the effluent was monitored at $197 \mathrm{~nm}$. Samples were dissolved in the buffer and injected by applying 5 mbar of pressure (10 s).

Aggregation Experiments. A 2\%(w/v) aqueous solution (50 $\mu \mathrm{L}$ ) of phospholipids $\mathbf{1}$ or $\mathbf{2}$ was injected in water or an aqueous solution containing $9 \mathrm{mM} \mathrm{CaCl}_{2}$ to a final concentration of $0.1 \%$ (w/v, phospholipid/water), sonicated for $15 \mathrm{~min}$ at $60{ }^{\circ} \mathrm{C}$, and then left to stand for $24 \mathrm{~h}$ at room temperature before electron microscopy samples were prepared. Samples were prepared by placing a drop of the dispersion onto a carbon-coated Formvarcover ed copper transmission el ectron microscopegrid. Theexcess of the dispersi on was removed after $1 \mathrm{~min}$ by blotting with filter paper, and subsequently the sample was dried and negatively stained with an aqueous $1 \%(\mathrm{w} / \mathrm{v})$ ammonium molybdate or $1 \%$ (w/v) uranyl acetatesolution. After 30 s theexcess of thestaining solution was removed by blotting with a filter paper and the specimen was dried for at least $4 \mathrm{~h}$ at room temperature.

Monolayer Experiments. All glassware was cleaned prior to use with a HF solution ( $10 \%$ in water $(\mathrm{v} / \mathrm{v}))$, washed several times with ultrapure water (Labconco Water Pro System, resistance $18 \mathrm{M} \Omega$ ), rinsed with ethanol (p.a. quality), and dried under a $\mathrm{N}_{2}$-flow. Monolayer experiments were performed with a themostated double-barrier R\&K trough $(6 \mathrm{~cm} \times 25 \mathrm{~cm})$ using a compression speed of $4.4 \mathrm{~cm}^{2} / \mathrm{min}$. The surface pressure of the monolayers was measured using a Wilhelmy plate which was calibrated with octadecanol. The surface of the compressed monolayers was studied with a Brewster anglemicroscope(NFT BAM-1) mounted on a home-built trough with dimensions 14.0 $\mathrm{cm} \times 21.0 \mathrm{~cm}$. The surface pressure was measured using Wilhelmy plates which were calibrated with octadecanol and were mounted on a Trans-Tek transducer (Connecticut, USA). The rate of compression was $4.4 \mathrm{~cm}^{2} / \mathrm{min}$. The surfactant was spread using a chloroform solution ( $\mathbf{1}$ and $\mathbf{2}$ ) or a chloroform/ methanol $(9 / 1(\mathrm{v} / \mathrm{v}))$ solution (3) $(10 \mu \mathrm{L}, 1 \mathrm{mg} / \mathrm{mL})$. Compression was started after $10 \mathrm{~min}$.

Crystallization Experiments. Supersaturated sol utions of cal cium bicarbonatewere prepared using the method of Kitano. ${ }^{22}$ Carbon dioxide gas was bubbled through a stirred aqueous (Labconco Water Pro System, resistance $18 \mathrm{M} \Omega$ ) suspension of $\mathrm{CaCO}_{3}(6.3 \mathrm{~g} / 2.5 \mathrm{~L})$ at a rate of $\sim 0.2 \mathrm{~m}^{3} \cdot \mathrm{h}^{-1}$ for a period of 1.5 $h$. The suspension was then filtered and the filtrate purged with

(22) Kitano, Y. Bull. Chem. Soc. J pn. 1962, 32, 1980. For further experimental details, see: (b) Rajam, S.; Heywood, B. R.; Walker, J . B. A.; Mann, S.; Davey, R.J .; Birchall, J. D.J . Chem. Soc., Faraday Trans. 1991, 87, 727. (c) Heywood, B. R.; Rajam, S.; Mann, S. J . Chem. Soc., Faraday Trans. 1991, 87, 735.

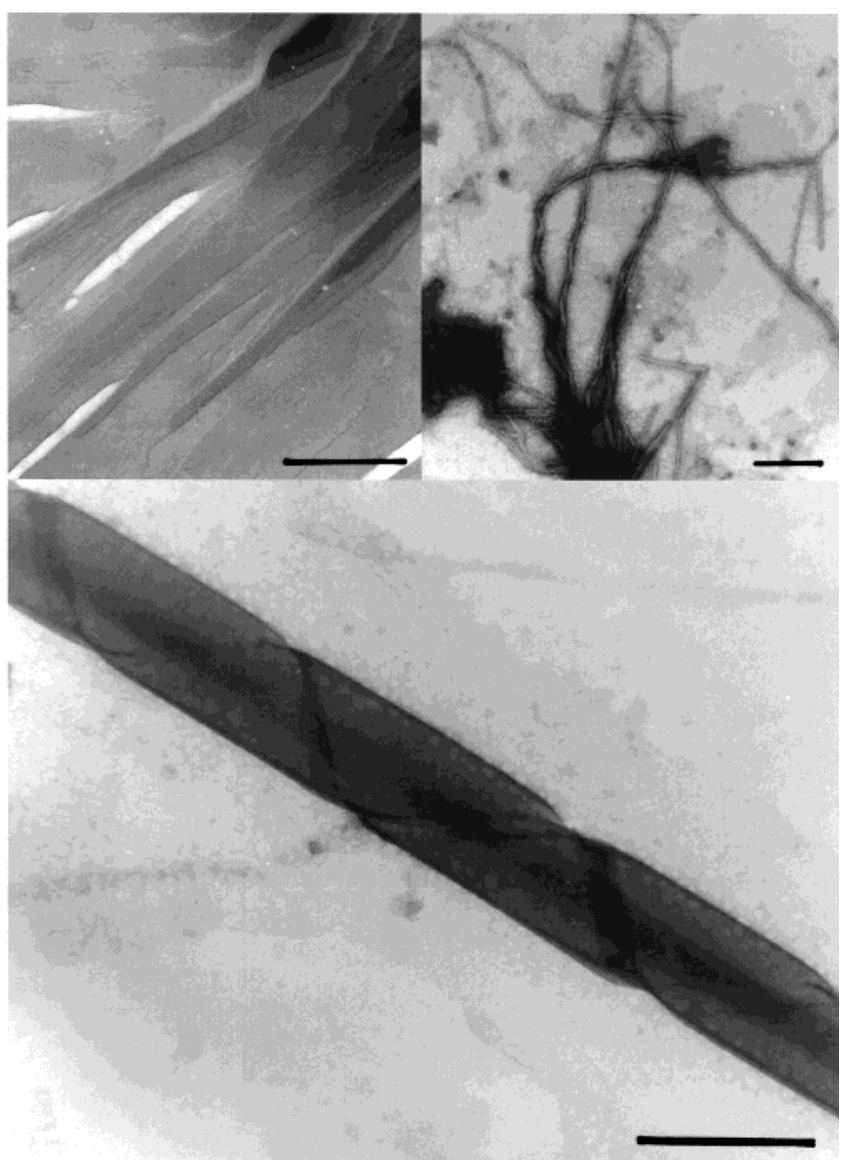

Figure 1. Electron micrographs taken from $0.1 \%(\mathrm{w} / \mathrm{w})$ dispersions of (a) $\mathbf{1}$ (Pt shadow technique, bar $250 \mathrm{~nm}$ ), (b) $\mathbf{1}$ after addition of $10 \mathrm{mM} \mathrm{CaCl}_{2}$ (negative staining, bar $500 \mathrm{~nm}$ ), and (c) $\mathbf{2}$ after addition of $10 \mathrm{mM} \mathrm{CaCl}_{2}$ (negative staining, bar $500 \mathrm{~nm})$.

carbon di oxide gas for $0.5 \mathrm{~h}$ to dissolve any remaining crystals. All crystallization experiments were performed in rigorously cleaned glass crystallization dishes. Compressed films were formed by adding known amounts of surfactant to generate a liquid-or solidlikefilmat theair - water interface. Crystals were harvested after $20 \mathrm{~h}$ on cover slips dipped through the films and were mounted on scanning el ectron microscope (SEM) specimen stubs. A J E OL T330 SEM operating at $15 \mathrm{keV}$ was used. Samples for TEM were collected by dipping Formvar-coated, carbonreinforced copper electron grids by slow dipping through the air-water interface. Excess fluid, collected during the dipping process, was removed immediately with filter paper, and the grids were left to dry in air. I mmature crystals were examined during the early stages of development $(t=10-30$ min after spreading of thesurfactant) using aJ EOL 2000F X high-resolution analytical el ectron microscopeoperating at $200 \mathrm{kV}$. Sel ected area electron diffraction patterns were recorded from the crystals. Crystallographic indices are presented in the three-index notation, using [uvw] axes and (hkl) faces, and are based on the unit cell of calcite.

\section{Results and Discussion}

Characterization of the Template. Aqueous dispersions $(0.1 \%, w / v)$ of phospholipid 1 were prepared by injecting an aqueous solution $(2 \%(\mathrm{w} / \mathrm{v}))$ of these compounds in water foll owed by sonicating at $60^{\circ} \mathrm{C}$ for $15 \mathrm{~min}$ and subsequent aging overnight. I nspection of thesamples with transmission electron microscopy revealed the formation of ribbons (Figure 1a). Addition of calcium ions toaqueous dispersions of $\mathbf{1}$ caused theformation of tubular structures (F igure $1 b$ ) with diameters ranging from 20 to $40 \mathrm{~nm}$. The finding that addition of calcium ions further 

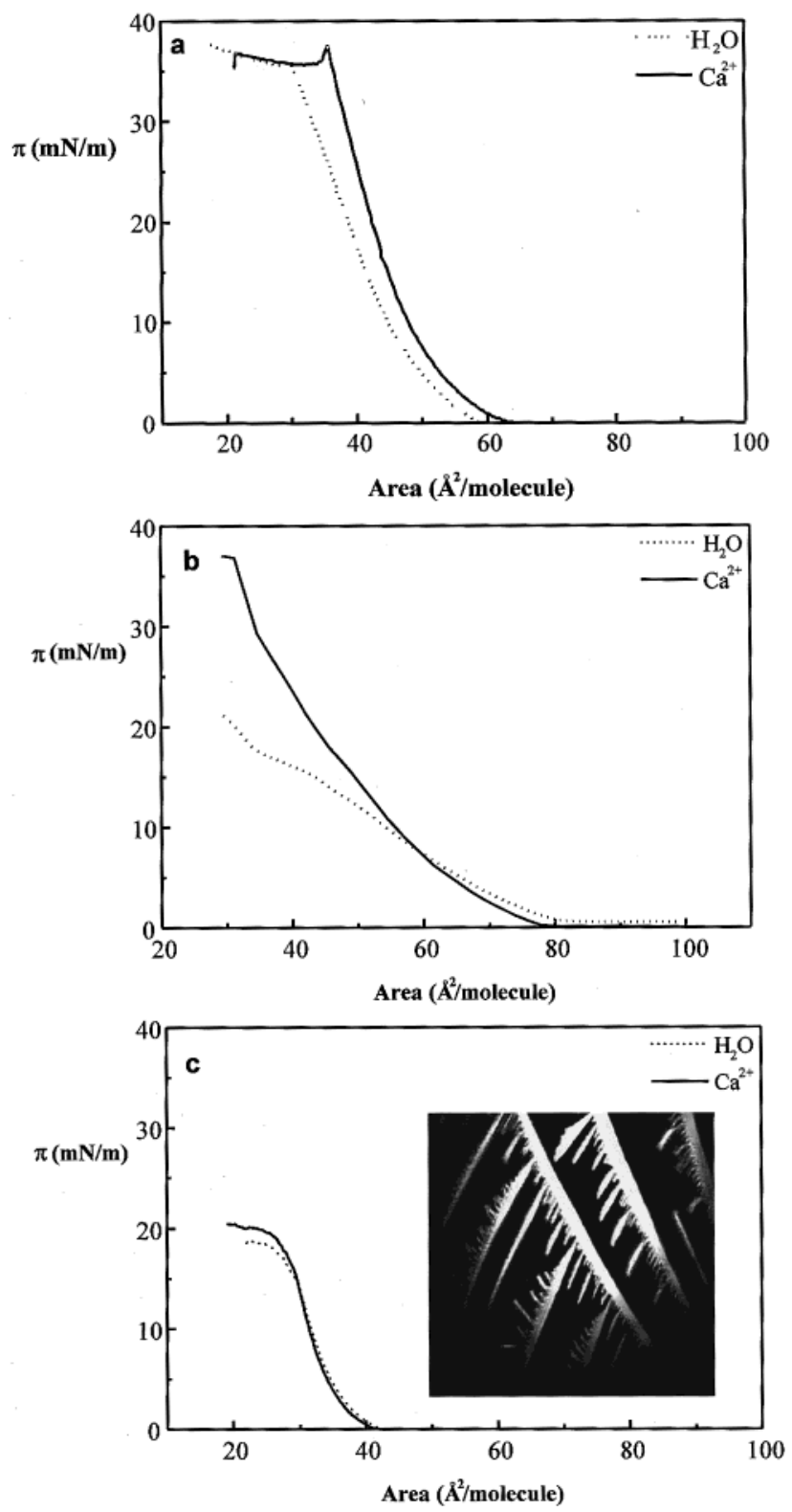

Figure 2. $\pi-A$ isotherms of monolayers of (a) $\mathbf{1}$, (b) $\mathbf{2}$, and (c) 3 at $20{ }^{\circ} \mathrm{C}$ on $(-) \mathrm{H}_{2} \mathrm{O}$ and $(--)$ aqueous $10 \mathrm{mM} \mathrm{CaCl}_{2}$. Inset to part c: Brewster angle micrograph of a surface monolayer of $\mathbf{3}$ on water at $20^{\circ} \mathrm{C}$ and $\pi=0 \mathrm{mN} / \mathrm{m}$.

enhances theorganization of these phospholipid molecules in the aggregates suggested that Langmuir films of these molecules could indeed be interesting templates for the crystallization of $\mathrm{CaCO}_{3}$.

For a Langmuir monolayer of compound 1 surface pressure-surface area $(\pi-\mathrm{A})$ isotherms were recorded from which a molecular area of $50 \AA^{2}$ was estimated by extrapolation of the curve to zero pressure. When spread on a subphase containing $9 \mathrm{mM} \mathrm{CaCl}$, compound $\mathbf{1}$ exhibited a significant interaction with the calcium ions present, as was deduced from a faster build-up of the surfacepressureupon compression (Figure2a). However, calcium complexation did not induce changes in the extrapolated molecular area. The observed higher lift-off area in the presence of $\mathrm{Ca}^{2+}$ suggests an increase in steric interactions between the molecules upon compression of the monolayer, which is attributed to interlinking of neighboring "ami de polymer chains" 17 through complexation of calcium ions. The film collapses at a limiting molecular area of $36 \AA^{2}$ when calcium ions are present
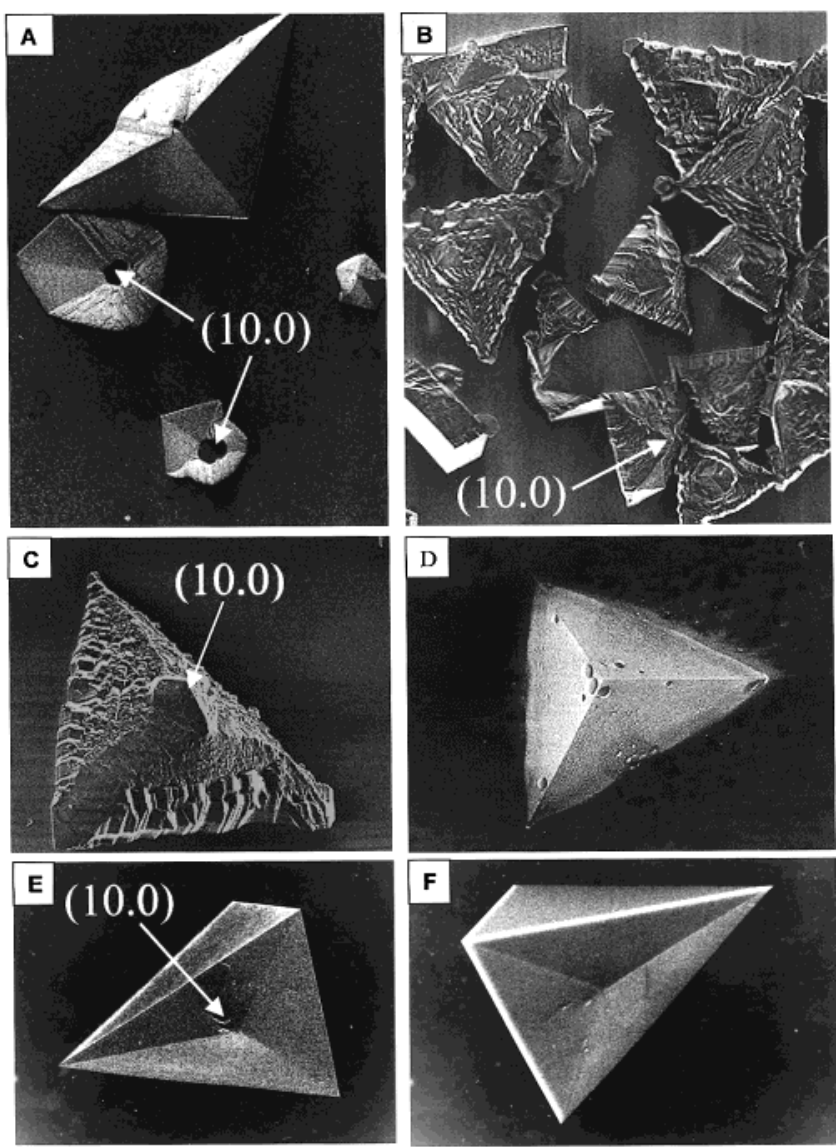

Figure 3. Scanning electron micrographs of calcite crystals grown (a) under liquidlike ( $60 \AA^{2} /$ molecule, $\left.\pi \sim 3 \mathrm{mN} / \mathrm{m}\right)$ and (b-d) in solidlike (40 $\AA^{2} /$ molecule, $\pi \sim 25 \mathrm{mN} / \mathrm{m}$ ) monol ayers of 1 and (e and f) under a solidlike (40 $\AA^{2} / \mathrm{molecule}, \pi \sim 25$ $\mathrm{mN} / \mathrm{m}$ ) monolayer of $\mathbf{2}$. Bars represent $10 \mu \mathrm{m}$.

and at $30 \AA^{2}$ when $\mathrm{Ca}^{2+}$ is absent, indicating that $\mathrm{Ca}^{2+}$ ions position themselves between the lipid headgroups.

Crystallization Experiments. Crystallization of calcium carbonate beneath a monolayer of $\mathbf{1}$ in its liquid state $\left(A=60 \AA^{2}, \pi=3 \mathrm{mN} / \mathrm{m}\right)$ resulted in the formation of oriented and discretecal citecrystals. Viewed fromabove themonolayer surface, the crystals had prismatic shapes with two $\{10.4\}$ faces being expressed with opposite to these faces a roughened side, as was observed with scanning el ectron mi croscopy (Figure $3 a$ ). ${ }^{23}$ I n most cases a flat apex was observed indicative of the location where the monolayer acted as a nucleation site. When a monolayer of 1 in a more solidlike state was used $\left(A=40 \AA^{2}\right.$; $\pi=25 \mathrm{mN} / \mathrm{m}$ ), the nucleation density was increased viz. from 330 to $490 \mathrm{~mm}^{-2} .24 \mathrm{In}$ both cases these values are high compared to values $\left(>106 \mathrm{~mm}^{-2}\right)$ reported for the nucleation of $\mathrm{CaCO}_{3}$ under monol ayers at the air-water interface; ${ }^{11}$ much higher values were obtained for self-

(23) In studies on templating monolayers, theformation of twotypes of calciteis observed; seeref 22b and: Mann, S.; Heywood, B. R.; Rajam, S.; Walker, J. B. A. ACS Symp. Ser. 1991, 444, 28. Type I exhibits pseudo- $C_{2 v}$ symmetry with all four basal $\{10.4\}$ faces expressed. Type II has pseudo- $C_{s}$ symmetry and is triangular in projection with only two of thefour basal edges being expressed. Typell calcitecan beformed through nucleation from different faces, that is, [00.1] (n-eicosyl sul phate) and [1-10] (stearic acid). The calcite formed in the present case is of type II and has nucleated from the (10.0) face. Type I calcite is thought to arise from a realignment and subsequent secondary growth of type II calcite at the monolayer surface.

(24) Under liquid expanded monolayers also a small amount of type I vaterite was formed (approximately $15 \%$ of the crystals). When the experiments wereperformed under compressed monol ayers, this number was reduced to approximately $8 \%$. 

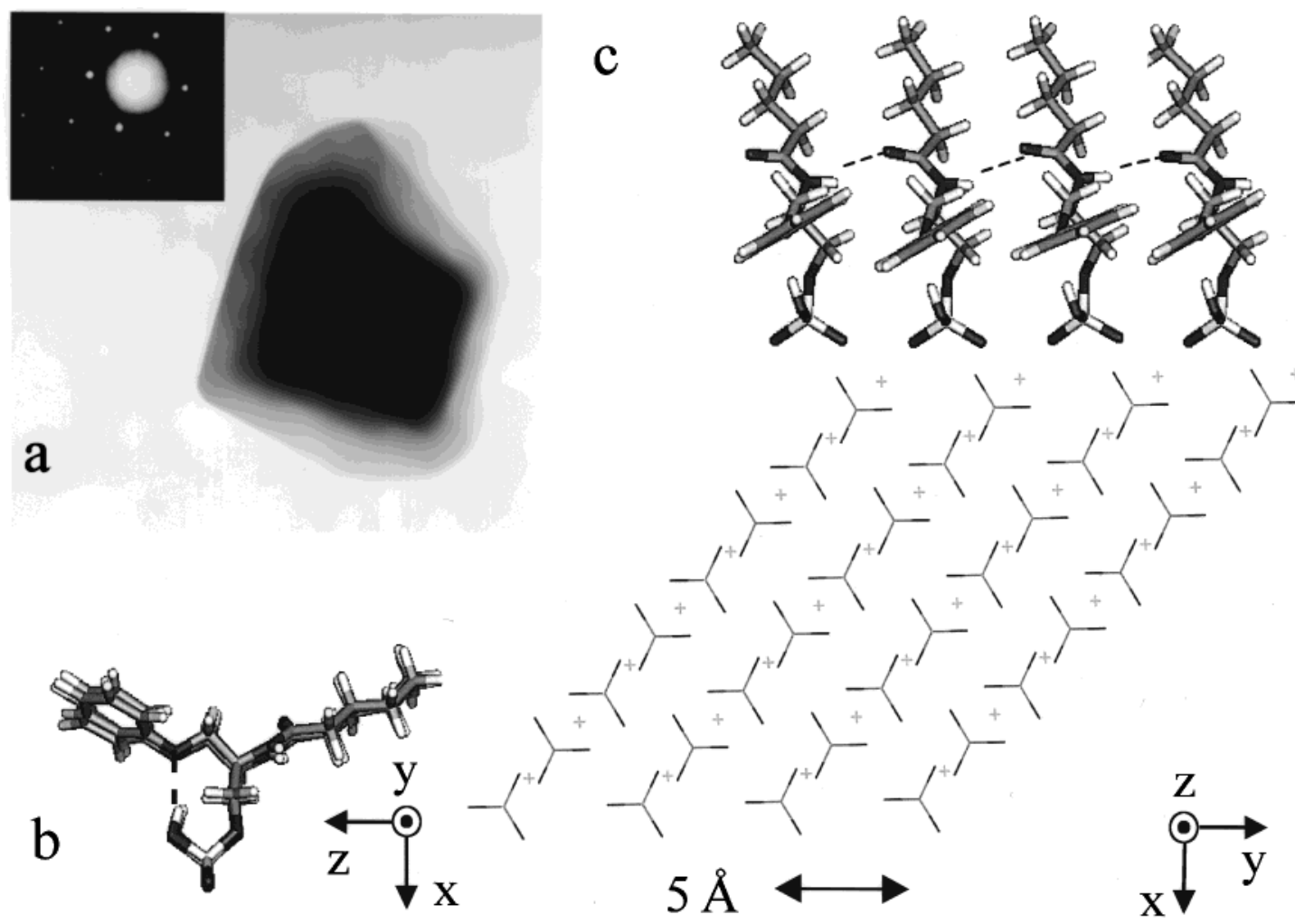

Figure 4. (a) Transmission el ectron micrograph and selected area el ectron diffraction pattern of an early [10.0] oriented calcite crystal grown under a monolayer of $\mathbf{1}$. (b-c) Computer generated models (b) of an assembly of molecules of $\mathbf{1}$ (viewed along the $y$-axis) showing the hydrogen bond between the phosphate group and the ether oxygen (the number of methylene groups in the al kyl chains is reduced for reasons of clarity) and (c) of the epitaxial matching of the (10.0) face of cal cite (generated with Cerius, ${ }^{2}$ "+" signs represent $\mathrm{Ca}^{2+}$ ions) with the phosphate oxygens in an assembly of molecules of $\mathbf{1}$. The Cartesian axes ( $\left.x, y, z\right)$ match the crystallographic axes (a, b, c).

assembled monolayers on gold. ${ }^{9}$ The morphological form of thesecrystals still was prismatic; however, in this case stepped surfaces wereobserved (Figure 3b). Thesestepped faces suggest a significant interaction of the growing crystal with the lipid monolayer. In contrast, when viewed from bel ow the monolayer, smooth $\{10.4\}$ rhombohedral faces wereobserved, indicating that with timethecrystals grow free of the constriction of the monolayer and down into the cal cium carbonate solution (Figure $3 d$ ). Electron diffraction studies were performed on crystals removed from the two crystallization assays after 10-30 min (Figure 4a). The observed patterns confirmed the formation of the calcite nature of the crystals and showed that the (10.0) face had been nucleated by the monolayer in both cases. This is remarkable, since monol ayers both of phosphates $^{16 \mathrm{~b}}$ and of phosphonates have been shown to nucleate the (00.1) face of calcite. In these cases the orientation of the carbonate ions was found to match the lattice of the template in which the phosphate and phosphonate headgroups possess a "tridentate" orientation, that is, an orientation in which three of the phosphate oxygen atoms are in the plane of the nucleated crystal face.

It was demonstrated in previous work that the amide hydrogen bonds fix the molecules of $\mathbf{1}$ in a linear array with an intermolecular distance of approximately $5 \AA .{ }^{17}$ Furthermore, it was indicated by FT-IR studies in conjunction with molecular modeling that an intramolecular hydrogen bond between one of the $\mathrm{P}-\mathrm{O}-\mathrm{H}$ groups and its ether oxygen was formed when the charges on the phosphate headgroups were compensated by protonation. ${ }^{25}$ In this situation the molecules of $\mathbf{1}$ adopt an arrangement in which the phosphate groups bend back, leaving only two of the phosphate oxygen atoms in contact with the aqueous phase, parallel to the "ami de polymers" (Figure 4b). We propose that the charge compensation arising from calcium ion binding leads to a similar bidentate headgroup structure with a $5 \AA$ repeat distance (Figure 4c). This motif indeed matches the orientation and spacing (4.99 $\AA$ ) of thecarbonateions al ong theb-axis in the (10.0) crystal face of calcite. In contrast, the molecular area of $50 \AA^{2}$ suggests that the interarray distance is $10 \AA$, which does not correspond very well to the carbonate-carbonate repeat distance of $8.53 \AA$ in this plane. However, the $\pi-\mathrm{A}$ isotherm shows that the mol ecules 1 can becompressed toan area of $36 \AA^{2} /$ mol ecule before the film ruptures, implying that a more dense packing which better matches the lattice spacings is well possible. Moreover, it has been demonstrated that the stereochemical and electrostatic matching can override quitewell the necessity of exact epitaxial matching of the lattice dimensions. ${ }^{11 a, 16 a}$

Effect of Headgroup Orientation on Epitaxial Matching. Toverify the proposed templating mechanism, that is, the necessity of hydrogen bond formation and bidental orientation of the headgroup for the epitaxial matching of the (10.0) crystal plane, compound $\mathbf{2}$ was prepared which carried one methyl substituent on its phosphate group. Under the conditions applied, the methylated phosphatemoiety of $\mathbf{2}$ cannot form a hydrogen bond with the phenoxy group, and ther efore, its headgroup will beconformationally less restricted than thephosphate group of $\mathbf{1}$. The interaction of $\mathbf{2}$ with calcium ions was again investigated first in aqueous dispersion, leading to the formation of left-handed helically wound multilayered

(25) L owering the $\mathrm{pH}$ also resulted in a higher degree of headgroup organization and in the formation of helical ribbons. ${ }^{17}$ 
ribbons (Figure 1c) with widths of $300-400 \mathrm{~nm}$ and a pitch of $1.0 \mu \mathrm{m}$.

The $\pi-\mathrm{A}$ isotherms obtained from this compound (Figure 2b) showed that thehigher conformational freedom and thelarger stericrepulsion of themethylated phosphate groups lead to the formation of a less preorganized monolayer. The complexation of calcium ions led to an increase in the organization of $\mathbf{2}$, but the observed lift-off area and compressi bility indicate that the mol ecules still have a lower tendency to pack in a compressed monolayer than those of $\mathbf{1}$. The compression isotherm revealed a molecular area of $48 \AA^{2} /$ mol ecule(deduced by extrapolation of the high-pressure part of the curve), which is close to the value obtained for compound $\mathbf{1}$. Molecular models again suggested an intermolecular distance of $5 \AA$ and showed that upon application of lateral pressure a headgroup structuresimilar tothat of $\mathbf{1}$, that is, a bidentate motif of the phosphate groups, is possible (Figure 4b). From this it was expected that only compressed monolayers of $\mathbf{2}$ could match the (10.0) face of calcite.

Indeed, $\mathrm{CaCO}_{3}$ grown under monolayers of 2 in theliquid expanded state gave almost no oriented crystals but randomly intergrown rhombohedral calcite (not shown). However, when monolayers in the compressed statewere used as templates $\left(A=40 \AA^{2}, \pi=23 \mathrm{mN} / \mathrm{m}\right)$, oriented calcite crystals were observed (Figure $3 e$ and f). These crystals had distorted trigonal bipyrimidal shapes with a small apex on of the top. The presumption that in a compressed monolayer thearrangement of the phosphate headgroups of $\mathbf{2}$ matches the (10.0) face of calcite was confirmed by electron diffraction performed on crystals recovered from the assay after $10-30 \mathrm{~min}$. Thenucl eation density of oriented crystal growth using films consisting of molecules of $\mathbf{2}$ was found to be significantly lower than that of $\mathbf{1}$ (approximately $50 \mathrm{~mm}^{-2}$ ), reflecting the lower degree of molecular organization in the template. ${ }^{26}$

To unequivocally establish the specificity of the templating effect, that is, to prove that the action of the phosphate group is essential and that the selective nucleation of the (10.0) face is not due to the presence of the other parts of the molecules, compound $\mathbf{3}$ was used as a control. Surface pressure-surfacearea $(\pi-A)$ isotherms were recorded from which it was calculated that on a water subphase compound $\mathbf{3}$ had a molecular area of 38 $\AA^{2} /$ mol ecule. ${ }^{27}$ This compound was found to generate a

(26) In addition, a significant amount of vaterite crystals was observed.

(27) Surfactant $\mathbf{3}$ was insoluble in water, and no distinct aggregate morphology could therefore be detected by transmission electron microscopy. condensed film upon compression (Figure 2c). Brewster angle microscopy ${ }^{28}$ (BAM) revealed that al ready at zero pressure very large 2D crystalline domains with dimensions on the order of millimeters were present. (Figure 2c, inset). ${ }^{29}$ When 3 was spread on an aqueous $9 \mathrm{mM} \mathrm{CaCl}{ }_{2}$ subphase, both the isotherm and BAM images were identical tothoseobtained on purewater, suggesting that the calcium ions did not interact with the monolayer. Crystallization experiments under monolayers of $\mathbf{3}$ did not reveal any interactions between the organic and the inorganic phases. After $20 \mathrm{~h}$ the predominant polymorph was calcite in the form of randomly intergrown rhombohedral crystals (not shown) which displayed no evidence of any preferred crystallographic orientation.

\section{Conclusion}

We have demonstrated that, in the presence of cal cium ions, amide-containing phospholipid $\mathbf{1}$ self-assembles to form well-defined two-dimensional domains that subsequently serve as templates for the crystallization of calcium carbonate. This leads to the efficient nucleation and growth of [10.0] oriented calcite irrespective of the surface concentration of the lipid. Responsible for this unexpected preference for nucleation at the (10.0) face is the high degree of organization in the self-assembled monolayers, in conjunction with the restricted conformational freedom of the headgroup of the molecule. This limited mobility is due to the formation of an intramolecular hydrogen bond between the phosphate group and the phenoxy moiety which forces the phosphate group to adopt a bidentate orientation toward the aqueous phase. It was shown that when this hydrogen bond was absent, lateral pressure was required in order to enforce a similar conformation and accomplish the nucleation of [10.0] oriented calcite.

Acknowledgment. The authors would like to thank A.E. Rowan (University of Nijmegen) for the molecular modeling and S.J . Williams (KeeleU niversity) for hel pful discussions.

\section{LA001765N}

(28) Hönig, D.; Möbius, D. J . Chem. Phys. 1991, 95, 4590. (b) Hénon C. A.; Meunier, J. Rev. Sci. Instrum. 1991, 62, 936.

(29) Thehigh degree of organization of themolecules of $\mathbf{3}$, as apparent from the B rewster angle micrographs, suggests the presence of a strong hydrogen bonding network. CPK models indeed indicatethat, in addition to the expected formation of linear arrays of amide groups, ${ }^{17}$ hydrogen bonds could be formed between the hydroxyl functions and the oxygen atoms of the phenoxy groups in neighboring molecules. The mol ecular area of $40 \AA^{2}$ deduced from these models is in good agreement with the value obtained from the $\pi-\mathrm{A}$ isotherm. 